\title{
Rethinking PG-13: Ratings and the Boundaries of Childhood and
}

\section{Horror}

The film rating system, established in 1968 by the Motion Pictures Association of America (MPAA), has remained remarkably consistent in structure throughout its history. Apart from some minor tweaks, the first - and to date, only - major change came in 1984, when a string of controversial features led to the creation of PG-13: "Parents strongly cautioned. Some material may be inappropriate for children under 13." This new classification was intended to bridge the gap between PG and the restricted R classification. If the rating system is intended to "reflect the current sentiment of parents" and "mirror contemporary concern" (The Classification and Rating Association), can this amend suggest important changes in society, particularly in relation to views of horror and childhood?

Regrettably, the importance of PG-13 has been systematically downplayed, often even ignored, in the academic context. In Stephen Vaughn's critical account of the rating system's history, for instance, the author frames the introduction of PG-13 around several cases of rating controversies of the early 1980s, most of which surprisingly refer not to PG or PG-13 films but to the R and X classifications and their "clearly flawed appeals process" (109). The importance of the restricted side of the ratings spectrum is so overpowering that the author concludes his analysis of PG-13 with a caveat, "there was still nothing to categorize the area between R and X" (120). In any case, Vaughn does subtly hint at why PG-13 may be important on its own: the violence and horror in Spielberg's family films such as Poltergeist (Tobe Hooper, 1982) and Indiana Jones and the Temple of Doom (Steven Spielberg, 1984), which were awarded the PG rating with minor struggle, were key to creating PG-13 (114-115) and prompted debates around the distinction "between teenagers and preteens" (117). 
This is a point worthy of much deeper consideration, particularly given the heated controversy generated by Temple of Doom upon release. Its violence and gore surprised viewers and upset parents, prompting Paramount to insert a warning in its advertisements for the film ("This film may be too intense for younger children") and Spielberg to clarify he would not let a 10-year-old see one of the film's most violent sequences (Harmetz). But if Temple of Doom was "the last straw [...] that broke the back of support for the single PG rating" (Goodman), its critical reception was, like that of Poltergeist, mostly positive. The issues around PG-13 become more complex when a third familyfriendly film, Gremlins (Joe Dante, 1984), is introduced to the group of PG-13 instigators. Unlike its predecessors, Gremlins, provoked strong critical ambiguity and an eruption of anxieties not only over the film's violence but also its tone and ideology, seen to be closer to horror than a family film. That PG-13 would then be perceived to appear as "a sop to the pressure, not as an initiative" (Champlin) suggests the early to mid-1980s as a period of transformation in social and cultural perceptions, in which PG-13 surfaces as the marker of new boundaries for childhood as well as the horror genre.

Debates about the film rating system have mainly been preoccupied with the topics of censorship and child protection, usually discussed separately. Discussions over censorship tend to limit themselves to the restricted end of the ratings spectrum and detail the problems surrounding the $X$ and NC-17 ratings, while authors who focus on child protection largely discuss the system's scope and the competence of its classifications, sometimes defending a change from age-based ratings to detailed content descriptions. ${ }^{1}$ Although the debates differ, the concerns raised on each side often meet, specifically in the questioning of the system's integrity and the MPAA's right to moral authority, as well as the consequences of the power it wields in Hollywood. ${ }^{2}$ Another point of contact between the two strands is the absence of criticism of the $\mathrm{R}$ rating. The restriction enforced by this classification - no children under 17 allowed without an adult guardian - is not only tolerated but apparently also demanded. Indeed, the debates in both of the strands outlined above can be traced back to one root problem: the dilution of the boundary set by the $\mathrm{R}$ rating. 
This dilution happens in two ways. On the restricted side of the $R$, the existence of another frontier, the X or NC-17 rating, "is turning us all into children" (This Film Is Not Yet Rated) by limiting the distribution of those films and, therefore, restricting content to adults. On the unrestricted side, the existence of PG-13 has exposed children to some adult content that was previously controlled, thus challenging the meaning and purpose of the $\mathrm{R}$ rating and opening the door to concerns over child protection. In other words, the $\mathrm{R}$ rating establishes an accepted distinction between children and adults and the content that is suitable for them, and this separation cannot be challenged (through changes either below or above the line) without tension and struggle.

The cultural weight of this distinction has also been demonstrated recently by a growing preoccupation with the "ratings creep." ${ }^{3}$ The "creep" refers to the gradual ways in which the R and PG-13 classifications have supposedly become more lenient and allowed more frequent and more intense adult content to become unrestricted. Supporters of this hypothesis sometimes refer to R films which, supposedly, would have been rated X or NC-17 in the past, but their greater focus is on PG-13, since it is the most successful at the box office as well as the highest unrestricted rating (and consequently, the most attractive to young viewers). The conclusions of "ratings creep" analyses are similar for all authors: the PG-13 rating has increasingly allowed more adult content to be passed without restriction, particularly violent images, therefore films rated PG-13 are not appropriate for the under-thirteen demographic.

While these analyses appear to be correct in their finding that adult content has been increasingly allowed in PG-13 films (as well as in other ratings), the "ratings creep" hypothesis is only valid if we are to believe that each classification has, or should have, a definitive and static definition. But, as MPAA's detractors often point out (This Film Is Not Yet Rated), the rating system has never had any concise criteria for its classifications; instead, the ratings are bound to external factors like society, culture, economy and the industry. The close link between social attitudes and the ratings is no mystery even to supporters of the "ratings creep" hypothesis, although these authors frame it as an 
exception rather than the rule. To explain the decline of comedy scenes involving alcohol abuse in unrestricted films, for instance, Leone and Barowski propose that "filmmakers, studios, and the MPAA have become more sensitized to [its] dire consequences" (MPAA Ratings Creep: A Longitudinal Analysis of the PG-13 Rating Category in US Movies 25). Furthermore, the conclusion that PG-13 is not suitable for children is a matter of opinion, depending on personal definitions of childhood and expectations of what is and is not suitable for children. In fact, despite persistent criticism, the rating system still appears to be well-liked by parents (The Classification and Rating Association), suggesting continued harmony between its classifications and the predominant values in America at a given time.

What interests me here, however, is not the validity of the modern "ratings creep" hypothesis but the way it repeats the concerns expressed three decades ago about PG-13 when the rating was first introduced, echoing a fear sometimes bordering on moral panic over the kind of entertainment available for children, as illustrated by accusations that "[PG-13 is] the Trojan horse in the movierating system - allowing wildly unsuitable material to smuggle its way past walls erected by even the most protective parents" (Medved). These preoccupations reveal a concern with notions of suitability and the boundaries of childhood, not only in relation to adulthood but also within childhood itself: as I will argue, PG-13 points to an alteration of the structure of childhood in western society in its distinction between early childhood (before the age of thirteen) and late childhood (adolescence). This segmentation may be culturally as important as the one between children and adults, as suggested by Medved's call for the substitution of PG-13 with R-13, a classification restricted for children under the age of thirteen.

In this article I will turn to the critical reception and promotional campaigns of Poltergeist, Temple of Doom and Gremlins for evidence of tension surrounding changing social attitudes and expectations in the period leading up to the introduction of PG-13. What I propose is that the rating controversies around these three films reveal a progressive intensification of struggles around the family and 
childhood, articulated through the horror genre, that culminate in the creation of PG-13. This classification therefore emerges as symbol of a new social and cultural agreement over a more segmented definition of childhood, as well as an indicator of changing views on horror, and, moreover, a landmark in the history of the film industry.

\section{Horror, violence and family values: Poltergeist; Temple of Doom}

Poltergeist and Indiana Jones and the Temple of Doom are the two earlier films usually named as instigators of the PG-13 rating. Although they tend to be critically and popularly framed as highly controversial films, I propose that the debates around them were in fact tempered by the films' image as family-friendly, raising questions not about suitability in general but specifically in relation to small children, thus suggesting impending segmentation of the concept of childhood.

Poltergeist caused trouble before its release; the film's innovative use of sound intensified scary moments beyond what the Classification \& Ratings Administration (CARA) committee felt was appropriate for young children. Poltergeist thus received an R classification - for terror - , which was quickly and successfully appealed for a PG on the grounds of the film being family-friendly (Vaughn 114). Free from restrictions, Poltergeist went on to become a box office triumph, now remembered as a classic. These events are noted by classification scholars like Vaughn and remembered by fans of film trivia but do not seem to have been perceived as major controversial points by critics of the period. Specifically reviewers of the film barely demonstrated concern over misclassification, biased appeals processes or the film's potential effects on young audiences. The review in Variety, for example, leaves out all comments on the audience to focus on critiques of the "truly stupid" story (Variety) and popular critic Roger Ebert described it as "the [horror] movie "The Amityville Horror' dreamed of being" (Ebert, Poltergeist), without ever questioning its suitability for young audiences or its place under the PG umbrella. 
This lack of public outrage is significant when paired with another trend in critical opinion of the period: the unquestioning acceptance of Poltergeist's affiliation with the horror genre. This acceptance, however, does not mean that this film was received as simply another horror film. As Kim Newman clarified, Poltergeist was "the horror equivalent of the exuberant, harmless, greatest show on Earth genre blockbusters (Star Wars, Raiders of the Lost Ark, E.T.: The Extra-Terrestrial)" (231). The warmth of Poltergeist's horror was equally noted by other critics. Vincent Canby of the New York Times described it as benevolent and "much closer in spirit and sensibility" to Spielberg's work, which has "preserved the wonderment of childhood," than to Tobe Hooper's R-rated Texas Chainsaw Massacre (1974) (Poltergeist (1982)).

Thus Poltergeist was read both as undeniably horror and undeniably benign, a paradox explained only by the film's ideological roots, much closer to the family film than to the horror genre. Take, for example, the critical responses to Carol Ann, the missing child: played by "cute little Heather O’Rourke" (Variety), Carol Ann is "an open-faced, long-haired, innocent little cherub" (Ebert, Poltergeist); a "small, blond beauty;" an "innocent hostage" (Canby, Poltergeist (1982)). These word choices embody in Carol Ann an idealized picture of childhood, and her mystique is so powerful it obliterates the other child character, Robbie, who is never mentioned by critics or exalted in the film. To be sure, if Carol Ann is other-worldly in her innocence, Robbie is firmly grounded on his passions and fears: his Star Wars memorabilia and childish fear of storms and clowns. Though these attributes make Robbie a more accurate portrait of a real child, it is Carol Ann who drives the film and entrances its audience - as the fictional family searches for their missing daughter, so does America pursue the lost childhood ideal. This utopia is entwined with a similar model of the family. Though it is far from perfect (as the parents' drug use suggests), the family's roots are sound by traditional conservative American standards: the father is a hard-working Reagan admirer and the mother has raised her children according to traditional Christian values. Indeed, Poltergeist evokes family values throughout, and references childhood favorites and classics, as noted by Kim Newman: 
Poltergeist's supernatural complainants are [...] childish: a cyclone and a grumpy tree from The Wizard of $\mathrm{Oz}$, and a fantasy land beyond the bedroom closet from The Lion, The Witch and the Wardrobe. Poltergeist may well be the only successful, non-spoof horror film in which nobody gets killed (231).

Thus Poltergeist takes shape as a family-friendly and ideologically conservative horror film that, outside of its initial ratings appeal process, did not cause controversy or social indignation. This does not exclude Poltergeist from discussions on the creation of PG-13 but an angle other than moral panics or industrial bias must be taken. As Newman suggested, Poltergeist was an anomaly within the horror genre. Its existence, as well as its success, reveal an emerging cultural interest in nonparody family-driven horror entertainment, later embodied in a wave of similar features in the 1980s and 1990s - Critters (Stephen Herek, 1986) and its sequels (1988, 1991 and 1992), The Gate (Tibor Takács, 1987), The Monster Squad (Fred Dekker, 1987) and Lady in White (Frank LaLoggia, 1988), as well as TV movies like Disney's Tower of Terror (D.J. Machale, 1997), among other titles. At this point in time, however, this idea is only a seed, not yet fully developed and therefore not yet in confrontation with the ratings system or the dominant social attitudes about children and horror.

Indiana Jones and the Temple of Doom was the next family film to cause ratings controversy. The debates are well-known and the film's use of violence has been credited as "instrumental in motivating the Motion Pictures Association of America to institute the PG-13 rating" (Friedman 103). But, as in the case of Poltergeist, critics were only partially conflicted about Temple of Doom's contents and its suitability for children. Roger Ebert, for example, wrote a positive review without a single mention of the film's violence and surrounding controversy. Similarly, the main point of contention for Todd McCarthy of Variety was the move "away from nifty stories in favor of one big effect after another," only briefly addressing violence and children. On that topic, McCarthy wrote: 
Kids 10-12 upwards will eat it all up, of course, but many of the images, particularly those involving a gruesome feast of live snakes, fried beetles, eyeball soup and monkey brains, and those in the sacrificial ceremony, might prove extraordinarily frightening to younger children who, indeed, are being catered to in this film by the presence of the adorable 12-year-old Ke Huy Quan.

Although this paragraph suggests a mild concern over the film's address to young audiences, McCarthy's choice to not develop these ideas any further is illustrative of the relative importance he gave them. On the other hand, McCarthy hints at Temple of Doom's specific demographic appeal "kids 10-12 upwards" - , a thought mirrored by other critics such as Pauline Kael - "there are sequences that are like what children dream up when they're having a gross-out and trying to top each other" (178) - and Vincent Canby:

If you've ever been a child or, barring that, if you've ever been around children, ages 7 to about 11, you may remember the sort of game in which each child attempts to come up with the vilest, most disgusting, most repulsive, most stomach-turning meal he can think of. [...]

The children squeal with delighted horror as each new dish is described, finding it all delicious fun, though any adults in the vicinity will probably feel sick.

The idea of a conflict between children and adults' reactions to the same scenes resurfaces later in Canby's piece, in relation to one of the film's most debated scenes: "a maharajah's banquet where the menu features the kind of dishes (live baby snakes, chilled monkey brains) that children will find simultaneously revolting and hilarious while the rest of us reach for our Tums." This adult repulsion at children finding delight in violence is expressed also in one of Canby's opening lines: "[feeling sick] may well be the public's reaction to Steven Spielberg's exuberantly tasteless and entertaining 'Indiana Jones and the Temple of Doom,' which [...] already is causing a ruckus because of its PG rating." The "ruckus" is thus attributed to Temple of Doom's lack of edifying content, content which 
panders to children's revolting dreams instead of regulating them with good morals, as traditional PG-rated children's and family films are thought to do.

If Poltergeist can be thought of as the seedling for the concept of family-oriented horror, Temple of Doom is the equivalent embryo for the acceptance of more violence in children's and family entertainment. Unlike Poltergeist, however, Temple of Doom generated much tension and anxiety. This is illustrated not only by the comments quoted above but, most especially, by the ambiguity which surrounded them. Vincent Canby's review for The New York Times provides a good illustration. Despite his criticisms and his warnings for parents ("contains a lot of explicit violence"), the critic's reprimands are only superficial. Indeed, Canby's descriptions of the film's violence are often framed positively, in a shy defense of the film's violent pleasures. Note the passage below:

There's no doubt about it - the movie, in addition to being endearingly disgusting, is violent in ways that may scare the wits out of some small patrons. The kidnapped Indian children, when finally found, are seen being flogged as they slave away deep in the maharajah's mines, though the flogging is so exaggerated that it seems less real than cartoon- like.

There's a vivid sequence in which a man, being offered to Kali, is slowly lowered into a fiery pit, but not before a priest has removed the victim's heart with his bare fingers. This, however, is not only a film-making trick but a trick within the film itself, something that older children may understand more readily than their adult guardians. Nevertheless, it's something to give parents pause.

Even if Canby is aware of the concerns of American parents and positions himself with them - "the rest of us" - his tone and choice of words suggest that his disapproval of Temple of Doom might be, at least in part, guided by social expectations. Canby's reticence, as with the rest of critical reception, establishes a sense of escalating tension from the release of Poltergeist to that of Temple of Doom. These films were pioneers of challenging ideas - family-oriented horror and violence in children's 
entertainment - and the controversy they generated around suitability for some but not all children had wider implications: had the PG rating become redundant or ineffective for early-1980s America?

\section{Ratings and the boundaries of childhood}

The PG rating is the common denominator to controversies around both Poltergeist and Temple of Doom. In the first case, PG was initially deemed inappropriate by CARA but later accepted by the public; in the second, PG was attributed by CARA and then contested by the public. I will now propose that the motives for these debates lied not in anxieties over the film's content as much as struggles over social changes, namely in the concept of childhood itself. Vincent Canby's review of Poltergeist provides the first piece of evidence in this direction. The critic wrote:

[Poltergeist is] a marvelously spooky ghost story that may possibly scare the wits out of very small children and offend those parents who believe that kids should be protected from their own, sometimes savage imaginations.

I suspect, however, that there's a vast audience of teen-agers and others who'll love this film. Indeed, Poltergeist often sounds as if it had been dictated by an exuberant twelve-year-old [...] (Canby, Poltergeist (1982)).

These paragraphs suggest a couple of things. First, the differences between children and adults' reactions to the same material and its potential for moral offense, specifically to do with the perceived need to protect children and control their fantasies. Second, an emergent distinction between "very small children" and "teen-agers and others," a group personified in the "exuberant twelve-year-old." The first point is related to on-going moral panics about youth; the second to the rating system's latent problem in the early 1980 s.

These are also topics that Canby addresses again, more extensively and more ambiguously, in his review of Temple of Doom. As quoted in the previous section, Canby again suggests that parental 
concerns on the matter of film violence may not match children's own reactions and attitudes - or, at the very least, not be an adequate reflection of children as a uniform demographic. As he had done for Poltergeist, Canby distinguishes between the different kinds of child audiences who may and may not appreciate Temple of Doom: where the film has strong affinity with the play of children aged seven to eleven, it may also frighten "some small patrons."

This division between young children and children around the age of eleven is also suggested in Variety's prediction that "kids 10-12 will eat it all up." In both of these reviews, the concerns over the film's violence are categorically deflected from a particular demographic — older children between the ages of seven and twelve - who both reviewers agree would enjoy the film greatly. Their concerns are instead aimed at the age group directly below: the small patrons, the "younger children."

The recurrent quality of this distinction is important, as it demands clarification of the usual claims that PG-13 was "a direct response to charges that the MPAA was soft on violence" (Prince 367). Indeed, the critical reception of Poltergeist and Temple of Doom points to a different problem: the PG rating was no longer able to signal suitability for both "very small children" and "kids 10-12." This conundrum may be what was behind Canby and other reviewers' ambiguous feelings toward Temple of Doom, a film that could not be recommended for all children but could also not be repudiated for all children uniformly - the rating system's scope, in particular its PG classification, no longer matched a notion of childhood most parents in America could agree on. This emerging idea of childhood as a segmented period was precisely how Steven Spielberg framed PG-13 when he first suggested the rating's creation to the president of the MPAA:

I remember calling Jack Valenti and suggesting to him that we need a rating between $R$ and $P G$, because so many films were falling into a netherworld, you know, of unfairness. Unfair that certain kids were exposed to Jaws, but also unfair that certain films were restricted, that kids who were 13, 14, 15 should be allowed to see (Windolf). 
Like some of the critics quoted above, Spielberg set a clear distinction between early childhood and late childhood, or adolescence, defending that different levels of violence and intensity could be appropriate for each group, while still respecting the frontier set by the R classification. There appears to have been consensus about the existence of this division, even if the exact moment of transition was debatable, varying from as young as seven to thirteen years old. Therefore, the anxiety, struggle and controversy can be traced back to a gradually intensified clash between social attitudes and social structures, affecting the rating system. PG-13 responded to these problems in a simple, yet majorly impactful way: it established a tangible middle-ground, an "official" separation between entertainment suitable for all children and features suitable only for older children and teenagers.

\section{Horror, violence and the desecration of America: Gremlins}

These issues are complicated further by the debates around the last film in the PG-13 trinity, Gremlins. If the reception of Poltergeist and Temple of Doom was heavy with anxiety over the segmentation of childhood and the inadequacy of the PG rating alone, these issues surfaces only rarely in relation to Gremlins, overshadowed by more serious moral concerns about the film's violence.

The shift in tone is illustrated by Vincent Canby's review. Similarly to Temple of Doom, Canby concludes his review of Gremlins with a warning about it not being "ideal entertainment for younger children" despite its PG rating; unlike he had done for Temple of Doom, however, the critic does not excuse the violence in Gremlins as child's play. On the contrary, Gremlins is "seriously mean" and "[attacks its] young audience as mercilessly as the creatures attack the characters." Canby wrote:

I've no idea how children will react to the sight of a Kingston Falls mom, carving knife in hand, decapitating one gremlin and shoving another into the food processor, head first. Will 
they laugh when Billy Peltzer, the film's idealized, intentionally dopey, 20-year-old hero, is threatened by a gremlin with a chainsaw and then stabbed by a gremlin with a spear gun? Will they cheer when Billy blows up the Kingston Falls movie theater, where the gremlins, now resembling an average kiddie matinee crowd, are exuberantly responding to "Snow White and the Seven Dwarfs" (Canby, Screen: 'Gremlins,' Kiddie Gore)?

These concerns were voiced by other critics. Roger Ebert, for whom the gremlins "turn into truly hateful creatures," wrote:

And the movie itself turns nasty, especially in a scene involving a monster that gets slammed in a microwave oven [...]. I had a queasy feeling that before long we'd be reading newspaper stories about kids who went home and tried the same thing with the family cat (Ebert, Gremlins).

In a similar vein, another critic wondered if the death scenes should be presented as funny in a children's film, remarking that he would "hate to be a cat or rabbit this Christmas." (Anon, Don't Feed After Midnight) This kind of preoccupation with the film's potentially nefarious effects on children was widespread but, curiously, the reason for its predominance seems to have been less the violence itself but rather the ideological context in which it was shown.

Both Poltergeist and Temple of Doom explore ideas of childhood innocence, the value of the family and the family as a powerful unit. This is especially clear in Temple of Doom, as it is only by uniting as a family that Indiana Jones, Willie and Short Round reach (literal) salvation: Indiana Jones rescues Short Round from death as an abandoned child by "adopting" him; Short Round exorcises Indiana's possession curse by declaring his filial love; and together they save Willie from the fires of hell, a Biblical punishment for the sins of pride, adultery and avarice to which she was prey. The film sanctified the family - in a moment reminiscent of the lepers' song in Jesus Christ Superstar (Norman Jewison, 1973), the natives kneel before Indiana's holy family —, and showed the demonic 
consequences of the destruction of this unit: morally corrupted or physically abused children, as well as tyranny and social misery.

This family ideal is an intrinsic part of American identity. As Ronald Reagan famously said, lesson number one about America is that all great change begins at the dinner table (Reagan's Farewell Speech). For this president, the family was "the basic unit of religious and moral values that hold our society together" (Radio Address to the Nation on Domestic Social Issues), and he encouraged Americans to teach family values to their children and "to have the courage to defend those values and virtues and the willingness to sacrifice for them" (Acceptance of the Republican Nomination for President). It is no surprise then that films which affirm these values could be more easily accepted than films which do not, irrespective of its violent content.

And, indeed, two ideas recur in reviews of Gremlins which may explain its mixed reception. The first is America, specifically "movie-made America, a dream of snow and Christmas and little dogs and angry ladies and nice neighbors" (M. Wood). The second is its destruction: "Capraesque Smalltown, U.S.A., [is subjected] to a devastation that makes the original 'Invasion of the Body Snatchers' look benign" (Canby, Screen: 'Gremlins,' Kiddie Gore). Moreover, a "Gremlins vs. America” theme was frequently explicitly noted by critics: "On the one hand, you have an idyllic American small town, with Burger Kings and Sears stores clustered merrily around the village square, and on the other hand you have a plague of reprehensible little beasties" (Ebert, Gremlins). Ebert restated this confrontation in conversation with Gene Siskel, describing Gremlins as "haunting the whole tradition of Norman Rockwell's Christmas, American Hollywood movie" (Siskel and Ebert). Or, in Pauline Kael's words, it "defiles [a] vision of the good American life;" it defiles "Frank Capraland" (188).

This opposition between Gremlins and American values is made especially problematic when the gremlins are compared to children. "The gremlins could be children who learn everything from TV, rock ' $n$ ' roll and B movies - and make the worst of it" (Corliss, Eek! Aaarrrgh! It's ET with Teeth); they are "children as seen by those who don't like them. Little devils, we say" (M. Wood). If the gremlins 
can be perceived as symbols for children, the conflict between this film and "the good American life" is intensified. Unlike Poltergeist and Temple of Doom, Gremlins does not sanctify family values but hops between praising and deconstructing them, starting with the notion of childhood innocence, a cornerstone of the other two films.

As well as questioning the notion of childhood innocence, through its depiction of the creatures, Gremlins also puts the nuclear family to the test in a series of challenges. First, it reduces the supposed patriarch, Mr. Peltzer, to a comic relief character, supported by his more successful son, Billy. Second, it establishes a second family unit through Billy's romantic pairing with Kate, only to leave the viewer wondering whether they "are meant to be a charming pair or a spoof of dopey wholesomeness" (Kael 189). Moreover, as Billy upstages his father so too he is surpassed by his "child," Gizmo, who is in turn overpowered (if temporarily) by the gremlins - thus establishing a chain of fathers made redundant by their progressively less innocent children. The end result of this continuum of destroyed families is comically illustrated by Mr. Futterman, Billy's neighbor who possesses unshakeable faith in the American way - it "can take anything!" Anything, that is, except gremlins, who later in the film take the wheel of Mr. Futterman's American-made plough and run it over its enthusiastic owner, his wife and their Christmas-decorated home.

The message of Gremlins, as summarized by a critic, is thus: "too many gizmos are rupturing the nuclear family; our children are out of control; Christmas kills" (Edelstein). The disparity between Gremlins' perspective and other family films, particularly those by Spielberg, was often noted. It was seen as a "black humorist's parody" of E.T. (Kael 188) and possessing "a very different character" to Poltergeist (Canby, Screen: 'Gremlins,' Kiddie Gore). Its ideology set it apart from the traditional family film, and its irreverence, although sometimes noted as a source of enjoyment, was also noted as improper - "I liked it too. Maybe I have a sick sense of humor" (Siskel and Ebert) — and frequently condemned: 
[Gremlins] is a black adult joke at the expense of innocence, all the more disturbing because children have been lured to it in America by its 'Parental Guidance' rating, though the kids with me in the cinema sat with the stiff, contorted limbs of coma victims as the movie turned from being a homely comedy into a house-of-horrors nightmare (Walker).

Here, Alexander Walker clearly indicated what made Gremlins so deeply problematic: the breach of the frontier set by the R rating and the unwelcome intrusion of horror in the realm of "homely comedies," the PG rating. The situation is framed around concerns of effects, but its reach is much broader: "Gremlins snatches the security blanket away from everything that has been held holy in children's movies - home, family, Christmas, religion and even the beloved memory of Walt Disney" (Walker). In other words, the combination of family and horror in Gremlins goes against the strongly established cultural zeal for the preservation of childhood innocence and its symbols (Jenkins).

What the example of Gremlins demonstrates is that there was a second layer of anxiety concerning the PG rating at this point in time, associated not just with changing notions of childhood but also with changing notions of the horror genre. To go back to my analogy of the three films as a ramp, Gremlins is the extrapolation of the changes explored by Poltergeist and Temple of Doom. In other words, if Poltergeist introduces the idea of horror for a family audience and Temple of Doom introduces the notion of acceptable levels of violence in children's entertainment, Gremlins puts the two together in a family-oriented horror film that has the themes and violence of a horror film as well as the kind of ideology associated with the genre. The implications are vast - for the rating system and American understandings of childhood, as I have already suggested in the previous sections, but also for the horror genre, which had previously been thought of as restricted and incompatible with children.

\section{Ratings and the boundaries of horror}


The issue which dominates the critical reception of Gremlins is precisely that of genre miscegenation and the viability of horror for a child audience, particularly under the PG classification. By and large, the focus was on the impossibility of such a combination. As quoted in the last section, Alexander Walker attributes the family-horror blend to malice, but others wrote about it differently, mostly using images of internal conflict: Pauline Kael described Dante's tone as “(perhaps deliberately) uncertain" (189); while Vincent Canby wrote about the "schizoid" personality of this "wiseacre mixture of [...] movie genres and movie sensibilities"' (Canby, Screen: 'Gremlins,' Kiddie Gore). The split between genres and sensibilities was often personified, in what Kim Newman called "a struggle between the world views of Spielberg and Dante" (185) and David Edelstein summed up as "Dante shitting all over Spielberg's never-never land, and Spielberg sugaring that excrement" (Edelstein).

This opposition between Spielberg and Dante's visions, however, was a fabricated notion as no tension between the two was ever reported and the two filmmakers seemed to be in agreement about the film's direction - not a battle of genres but a marriage (White). To be sure, the real opposition the critics allude to may be less between Dante and Spielberg than about what they represent, i.e. Dante for horror, the R rating and anarchic ideology; Spielberg for the family film, the PG rating and traditional family values. The critical insistence on this fictional antagonism is significant in its suggestion of the family/ horror combination as culturally anathema, a union so challenging it could only exist in the context of an artificial polarization between filmmakers.

This suggestion gains strength when we consider the disparities between the film's narrative and its promotional campaigns. From the way Spielberg and Dante handled the original script, we can deduce an intension to blend the genres of horror and family as seamlessly as possible, with cuts, edits and plot changes made specifically to reduce the film's intensity but without altering its horror elements. For example, in one of the few death scenes that survived the filmmakers' changes, the script called for the science teacher to be stabbed in the face with several needles - with a touch of humor, this was changed to a single needle on the buttocks (White). 
The most impactful change, however, was the inclusion of Gizmo. In the original script, Gizmo appeared only in the first scenes and quickly turned into the leader of the gremlin pack. Spielberg wanted to keep Gizmo an ally all the way and so Stripe was introduced as the new villain, a change Joe Dante credits with making the film "much more accessible" (Chute n. pag). The added accessibility may come from a distancing from the horror genre: in the original script, Gizmo's transformation into a gremlin put him in direct conflict with his father figure, Billy, who ultimately destroys him - a plotline strikingly similar to horror narratives featuring the Terrible Child motif (R. Wood), such as Village of the Damned (Wolf Rilla, 1960), The Omen (Richard Donner, 1976) and others, which often climax in infanticide. The persistency of Gizmo as a cuddly pet, on the other hand, brings Gremlins closer to family narratives like E.T..

Despite these attempts to find a middle-ground, not much of the horror side of the film seems to have travelled outside the text. "I think people were upset," Joe Dante has said in interview, "[to have taken] a 4-year-old to see 'Gremlins,' thinking it's going to be a cuddly, funny animal movie and then seeing that it turns into a horror picture" (Breznican). Indeed, although the filmmakers attempted a balance between horror and family entertainment, the marketing - much like the critics quoted earlier - insisted on a separation between the two. In contrast with those critics, however, the marketing of Gremlins did not present this separation as a conflict. Quite simply, it disregarded the horror elements in Gremlins and presented it according to the regular expectations of a PG-rated family film.

The trailers and television adverts, for example, heavily emphasized the film's connection to Spielberg, imitating "the color and style of the 'E.T.' ads" (Breznican), and opening with the words "Steven Spielberg presents." The editing of these spots also sought to remind audiences of Spielberg's work, highlighting the comedy, romance and adventure aspects of the film, as well as Gizmo's cute appeal. In contrast, Joe Dante was only mentioned briefly at the end, while the scenes of horror with the gremlins were omitted or framed in humor. 
The same strategy was used in the merchandise, which was dominated by Gizmo. He featured on the box of Gremlins breakfast cereal, jigsaw puzzles, stationary, apparel, stickers and transfers; and was sold as stuffed animal, action figure, singing doll, in wind-up cars, as well as in an array of bendable figurines, water hatchers and other assorted toys. Fast food chain Hardee's sold five Gremlins story books and records that, despite being direct adaptations of the film's story and not tie-in fictions, were described in the television advert as "stories about Gizmo and his friends." Further testament to the mogwai's popularity was the Gizmo version of Furby, an interactive electronic pet, released in 1999 by Tiger Electronics - as well as the number of other pets named after him, both real and fictional, such as the family dog in True Lies (James Cameron, 1994).

But this Gizmomania was selective: the mogwai was restricted to gentle and cheerful representations. This is in direct contrast with the film, where Gizmo spends most of his time weeping, screaming and trembling in distress. Far from being the singing, cooing sweet little creature the merchandise implies him to be, film-Gizmo is constantly found in situations of extreme danger - like being pinned to a darts board -, in a state of overwhelming anxiety - caused by the "bright light!" and the concerning development of the other creatures -, or in the process of killing one of his kind, Stripe.

Images of the other gremlins underwent a similar process of selection. Pauline Kael found it apt to describe them as "aggressively vulgar [...] children of the night" (188), but in the several merchandise lines the gremlins are portrayed as simply puerile. In an obviously secondary place to Gizmo, the gremlins feature mostly in stationery and party items, such as those produced by Hallmark Ambassador, or humorous action figures, like those made by NECA. As Gizmo was sanitized so were the gremlins: the film's drunk and murderous vandals become harmless clowns. This domestication was often extended to the film's villain, Stripe. Though he is portrayed as the villain in many of the toys and action figures, he is also frequently relegated to the background- as in an action figure set by LJN that lists him as a nameless "gremlin" — or in portrayals that present him as a thrill-seeking 
prankster instead of an evil monster - "Where's the party?" he asks in an Hallmark card invitation. The disparity is so strong even one of the advertisements points it out: "If you've seen the new movie 'Gremlins' [...] you know how troublesome the gremlins can be. But at Hallmark, our gremlins are as tame as Gizmo."

Ideas of family-friendly fun were emphasized further by the marketing's heavy reliance on Christmas themes. Taking advantage of the film's winter setting, the main lines were released for the holiday season, replete with images of Gizmo dressed as Santa Claus and carolling gremlins. Certainly there is nothing unusual about a desire to capitalize on Christmas sales, however, this marketing decision was at odds with the film's box office tactic: Gremlins was released in the summer in order to avoid being labeled a Christmas film (White). Furthermore, there was another popular holiday happening much closer to the film's release Halloween. Yet, despite the many horror elements in the film, no scary toys were ever made nor were there plans for Halloween line. Thus, the merchandise strategy suggests two decisions: that only one of the two possible holidays was to be embraced, and that this holiday should be Christmas. Again, the idea of family (Christmas) and horror (Halloween) coexisting is firmly rejected, with the presence of one serving as antidote for the other. This strategy was so widespread that in Britain, after Gremlins was given a restricted rating, Warner's vice-president Julian Senior came to its defense with a simple statement, "I think it is a lovely Christmas movie" (Anon, Gremlins! Will You Let Your Children See Them?).

These discrepancies between the marketing and the text of Gremlins are revealing of conflicting attitudes and expectations of genres, childhood and the PG rating. Spielberg and Dante's attempt to negotiate horror and family entertainment is in line with my previous suggestion of a more segmented concept of childhood - the idea that there was a demographic between the PG and R rating for whom this level of intensity was appropriate - but it also suggests an attempt to renegotiate the boundaries of the horror genre, bringing it below the $\mathrm{R}$ frontier. 
The responses to their work, on the other hand, illustrate the degree to which this was an uncomfortable thought: critics explained it through a conflict, while the marketing choices remade Gremlins to anchor it on the expectations of a traditional family film. Both point towards a cultural repulsion for the combining of horror and children, but their suggestion of a social agreement over the boundaries of horror is far from universal. On the contrary, the strength of these responses is matched by the film's popularity at the box office and beyond - the will to unite family and horror appears to have been more than Spielberg's whimsy. As before, PG-13 responds to these struggles by establishing a tangible middle ground: horror is no longer entirely restricted but it is still not endorsed for all child audiences.

\section{Conclusion}

"There used to be children's movies and adult movies," wrote Ebert a year after the introduction of PG-13. "Now Spielberg has found an in-between niche, for young teenagers who have fairly sophisticated tastes in horror." (The Goonies) This comment sums up the cultural shift I have been exploring in this article. From Poltergeist to PG-13, film culture adapted to the notion of child- and family-friendly horror. As PG-13 bridged the PG and R classifications, the concept of childhood became as segmented as the new rating system: minors were no longer a uniform block but two clearly separated demographics, children and teenagers. A new transition stage between these two groups also emerged, timidly at first and then more persistently, taking shape in the figure of the pre-teen. Concepts associated with traditional childhood, such as family values, were equally transformed, and even questioned. Entertainment for families and children had previously been associated with Walt Disney, Norman Rockwell and Spielberg's E.T., but these memories were gradually rejected in favor of unconventional reference points, such as violent adventure and horror. The result was a drastic ideological shift, from the exaltation of childhood innocence in Poltergeist to its tentative obliteration in Gremlins. The gateway now open, horror-flavored PG and PG-13 films 
bloomed in the late 1980s: Critters (Stephen Herek, 1896) and its sequels, as well as The Gate and The Monster Squad, to mention only a few. But the transformations went beyond the family film and deep into the horror genre, where despite initial hospitality the idea of horror for young audiences proved troublesome. The characteristics of horror which fans appreciated, and which had previously been taken for granted, such as its unsuitability for children, its violence and edginess, were being put to the test, and the question of where to draw the line became a concern of the genre, not to mention parents and critics.

It is clear that PG-13 signals a major milestone, not just industrial but also social and cultural. As I have explored here, its creation was deeply rooted in American attitudes and cultural transformation in the 1980s. Today, in its third decade of life, PG-13 continues to tell us much about American society and culture - including on the topics of childhood and horror. Consider, for example, its contemporary presence in the horror genre. PG-13 is "safe-as-milk" (Goldstein), and its stigma is strong: "I don't want Spawn to be PG-13; I want the movie to be R-Rated. I want it to be a scary movie," declared writer Todd McFarlane (Hanley), while Fangoria staff considered the films currently being "sanitized for PG-13 audiences" and wondered "how much more fun those same teens would have picking that R-rated film [...] and taking a fucking risk for a change" (Hanley, Tales from the Video Store: The [R]ite of Passage).

The associations between horror, the $\mathrm{R}$ rating and edgy content are so prevalent that distinctions between PG-13 and the other unrestricted ratings are sometimes considered extraneous, as is the rating's historical context. An article on Horror-Movies.Ca, for instance, set out to list the best PG-13 horror films but only included six PG-13 films, with the remaining choices (and two of the top titles) predating the rating's introduction (Anon, Top Ten PG-13 Horror Movies). What taints PG-13 for some horror fans today is exactly what prompted its creation in the 1980s: young audiences. When Gil Kenan, known for child-friendly output, was announced as the director for the 2015 remake of Poltergeist, Fangoria magazine wondered if the filmmaker would remain true to the layered original 
or "just aim lower" (Zimmerman). These worries were shared by the staff at Horror-Movies.Ca, who saw "red flags" when an actor revealed the project to be "more of a kids' movie" (McDonald). This kind of cynicism is common enough. Another online article, revealingly titled "In Defense of PG-13 Horror," begins by asserting that PG-13 films are "often a ploy to sell tickets to the 'tween audience, rather than deliver a quality and well-crafted fright film." The article then includes examples of films which "rose above" or "pushed" the PG-13 rating, not defending PG-13 horror at all but rather highlighting exceptional cases (Doupe). Indeed, as A.V. Club writers declare, "It's a rare thing when a PG-13 horror movie actually stands out for its ability to evoke fear." Instead, PG-13 means "embarrassing compromise," it means "filmmakers had to water down their content for a young audience, and the results are often half-hearted, vapid, or muddled" (Dyess-Nugent, Rabin and Robinson). This is a criticism far from limited to the horror genre. In a piece titled "The ongoing failure of the PG-13 rating," Chris Klimek pondered the ratings of continuing action franchises:

What's puzzling is that these studios believed these pictures needed the PG-13 to be successful. [...] Exactly how many 16-year-olds did 20th Century Fox imagine were interested in the continuing adventures of a 52-year-old, confused-by-the-Internet Bruce Willis in 2007? [...] While it started off soundly, the PG-13 rating now represents the insidious idea that filmmakers working above a certain budget level can no longer decide who their films are for.

Where family and children's films are concerned, the criticism of PG-13 takes a slightly different shape. Writing for The Atlantic, Garin Pirnia argued that the reason for the downfall of youthoriented films is not that filmmakers do not know which audience they want but that they know which they do not: pre-teens and families. According to Pirnia, the golden years of youth-oriented films were a very precise moment in time - it began with Gremlins and Temple of Doom, peaked the year after PG-13's creation and then steadily declined, "leaving the genre almost dead by the end of the decade." Afterwards, the situation has only declined further, as from the advent of the 
Harry Potter and Lord of the Rings franchises in 2001 youth-oriented films have been almost exclusively blockbusters or animated films, with nothing in between. Pirnia is not alone in this preoccupation. Todd Brown, editor of Twitch, believes that "PG-13 has led directly to the end of films specifically tailored to the 10-13 age range." He wrote:

[S]ince the PG-13 the movie industry sees children only as those over the age of thirteen and those under the age of thirteen. [...] This means that if you're setting out to make a PG-13 movie you want to make one that will appeal to fifteen to seventeen year olds. [...] And if you're setting out to make a film for children under thirteen it makes sense to spend the bulk of your money making movies that mom and dad will go to with their children and that means aiming young. [...]The problem here is that kids aged ten to thirteen are nothing at all like seven year olds or fifteen year olds and they're getting cut out entirely.

There is a sense of tragic irony here. PG-13 was introduced as a response to the growing realisation that young people under seventeen were not all the same, and yet the rating's existence seems to have pushed the film industry back to a similar culture of homogenization. But more interesting still, there is some social pressure to increase this homogenization. Common Sense Media, a children's advocacy group, has launched the Campaign for a Commercial Free Childhood (CCFC), which has repeatedly petitioned the MPAA to rethink PG-13, particularly its lack of limits on advertising, which often targets children under the age of thirteen. The argument is that marketing campaigns such as toy lines may cause parents to make inaccurate assumptions about film content, as they "weaken the statement 'strongly cautioned' [in the rating's description] and add to the ambiguity of the phrase 'may be inappropriate'" (Letter to the MPAA 2).

Campaigns like this highlight anxieties over the media and parental authority in their suggestion that parents are undermined by popular culture, especially when it comes to young children: 
While it is easy to argue that parents should "just say no" to requests from children to view violent media, it is important to remember that marketing for PG-13 movies takes place in the midst of an avalanche of other kinds of marketing for all sorts of other potentially unsuitable products including junk food, violent videogames, and sexualized clothing. [...] [E]ven parents who limit children's TV viewing [...] have to cope with the results of children who see those ads. [...] [E]ven parents who refuse to let their children watch television at all are negatively affected because it is likely that their children will be subject to peer pressure [...] from children whose parents do not set the same limits". (Letter to the MPAA 3)

Though this particular campaign did not call for PG-13 to become a restricted classification as others have done (Medved), the petitioners' recommendations point toward the complete removal of PG13 films from children's culture, including very strict television advertising rules, a restructuring of toy ratings and the prohibition of restaurant tie-ins and promotions (Letter to the MPAA 4). Campaigns like this add to the concerns expressed by critics like Brown and Pirnia and the sense that the pre-teen demographic, so pivotal in the 1980s, is now trampled by stronger forces: on one side, artistic freedom and profit, on the other the protection of young children.

There are, of course, exceptions to this tendency in film, though they are few and far between, and often come from a place of nostalgia - for the 1980s, for horror movies, for pre-adolescence. The most notable recent example is Super 8 (J.J. Abrams, 2013). Described as "a poetic rendering of preadolescent anguish in a horror-film setting" (Corliss, Super 8: Just as Great as You Hoped It Would Be), the film's look and characters recalled "not just early Spielberg but ' 80 s favourites Stand By Me and The Monster Squad" (Graham). It's nostalgia, however, was not "for a time," as noted by Ebert in his review, "but for a style of filmmaking, when shell-shocked young audiences were told a story and not pounded over the head with aggressive action. Abrams treats early adolescence with tenderness and affection" (Super 8). Ebert's observation is in itself nostalgic for that time - back in 1985 the critic wrote how in Goonies, much like in Gremlins, "Spielberg is congratulating [children] 
on their ability to take the heavy-duty stuff" (The Goonies). This view of young teenagers is echoed in Brown's criticism of PG-13: "people actually want [stories like Super 8], as opposed to the overly sanitized, overly safe tales that we normally get. [...] [I]t's time the film industry caught up and took [pre-teens] seriously."

Much has changed since the 1980s but much has also stayed the same. Just as horror still hesitates between embracing and repudiating young audiences, the concepts of childhood, its boundaries and the precarious balance of media suitability continue to ignite debate. As the convergence point of these tensions, PG-13 remains a heated battleground, posing myriad questions about American values, attitudes and ever-changing culture.

\section{Works Cited}

Anon. "Don't Feed After Midnight." Nine to Five 10 December 1984: n. pag. Print.

—. "Gremlins! Will You Let Your Children See Them?" Daily Express 2 October 1984: n. pag. Print.

-. Top Ten PG-13 Horror Movies. 16 March 2013. Web. 26 January 2015.

Barker, Martin and Julian Petley. III Effects: The Media/Violence Debate. London: Routledge, 1997. Print.

Breznican, Anthony. "PG-13 Remade Hollywood Ratings System." 23 August 2004. Seattle Pi. Web. 26 May 2014.

Brown, Todd. How the PG-13 Killed The Films It Was Meant To Save. 13 March 2011. Web. 25 March 2015.

Buckingham, David. Moving Images: Understanding Children's Emotional Responses to Television. New York: St Martin's Press, 1996. Print.

Bushman, Brad J. and Joanne Cantor. "Media Ratings for Violence and Sex: Implications for Policymakers and Parents." American Psychologist 58.2 (2003): 130-141. Print.

Bushman, Brad J., et al. "Gun Violence Trends in Movies." Pediatrics (2013): n. pag. Web.

Campaign for a Commercial-Free Childhood. "Letter to the MPAA." 17 January 2008.

CommercialFreeChildhood.Org. Web. 1 January 2015. 
Canby, Vincent. "Poltergeist (1982)." 4 June 1982. The New York Times. Web. 26 May 2014.

—. "Screen: 'Gremlins,' Kiddie Gore." 8 June 1984. The New York Times. Web. 26 May 2014.

—. "Screen: 'Indiana Jones,' Directed by Spielberg." 23 May 1984. The New York Times. Web. 26 May 2014.

Cantor, Joanne. Mommy, I'm Scared: How TV and Movies Frighten Children and What We Can Do To Protect Them. San Diego, California: Harcourt, Brace \& Co., 1998. Print.

Champlin, Charles. "PG-13: a Cynical Industry's Panacea?" Sarasota Herald-Tribune 14 July 1984: 77. Print.

Chute, David. Film Comment May-June 1984: n. pag. Print.

Corliss, Richard. "Eek! Aaarrrgh! It's ET with Teeth." Time Magazine 2 July 1984: n. pag. Print.

—. "Super 8: Just as Great as You Hoped It Would Be." 2 June 2011. Time. Web. 5 April 2015.

Doupe, Tyler. In Defense of PG-13 Horror. n.d. Web. 5 March 2015.

Dyess-Nugent, Phil, et al. Extra terror, hold the gore: 8 truly scary PG-13 horror movies. 23 January 2013. Web. 5 March 2015.

Ebert, Roger. "Gremlins." 1 January 1984. RogerEbert.com. Web. 26 May 2014.

—. "Indiana Jones and the Temple of Doom." 23 May 1984. RogerEbert.com. Web. 26 May 2014.

-. "Poltergeist." 1 June 1982. RogerEbert.com. Web. 26 May 2014.

—. "Super 8." 8 June 2011. RogerEbert.Com. Web. 5 April 2015.

—. "The Goonies." 1 January 1985. RogerEbert.com. Web. 15 January 2015.

Edelstein, David. Voice 24 July 1984. Print.

Friedman, Lester D. Citizen Spielberg. Urbana: University of Illinois Press, 2006. Print.

Gentile, David A. "Media Ratings for Movies, Music, Video Games, and Television: a Review of the Research and Recommendations for Improvements." Adolescent Medicine Clinics (2005): n.pag. Web.

Goldstein, Patrick. "Guillermo del Toro Blames R Rating For Madness Project Going Dark." 9 March 2011. Los Angeles Times. Web. 16 January 2015.

Goodman, Ellen. "Change the Films, Not the Ratings." Los Angeles Times 26 June 1984: C5. Print.

Graham, Jamie. Super 8 Review. 1 June 2011. Web. 5 April 2015.

Hanley, Ken W. "Tales from the Video Store: The [R]ite of Passage." 11 February 2015. Fangoria. Web. 28 March 2015. 
-. "Toys of Terror \#14.5: Q\&A with Todd McFarlane!" 11 July 2014. Fangoria. Web. 16 January 2015.

Harmetz, Aljean. "'Indiana Jones' May Spell Doom For Current Movie Rating System." The Palm Beach Post 23 May 1984: 48. Print.

Jenkins, Henry. The Children's Culture Reader. New York: New York University Press, 1998. Print.

Kael, Pauline. State of the Art: Film Writings 1983-1985. London: Marion Boyars, 1987. Print.

Klimek, Chris. The ongoing failure of the PG-13 rating. 4 December 2014. Web. 5 January 2015.

Leone, Ron and Laurie Barowski. "MPAA Ratings Creep: A Longitudinal Analysis of the PG-13 Rating Category in US Movies." Journal of Children and Media 5.1 (2011): 53-68. Web.

Leone, Ron and Lynn Osborn. "Hollywood's Triumph: An Examination of the PG-13 Rating." Popular Communication: the International Journal of Media and Culture (2004): 85-101. Print.

Leone, Ron and Nicole Houle. "21st Century Ratings Creep: PG-13 and R." Communication Research Reports 23.1 (2006): 53-61. Print.

Lewis, Jon. Hollywood v. Hard Core: How the Struggle Over Censorship Saved the Modern Film Industry. New York: New York University Press, 2000. Print.

McCarthy, Todd. "Review: 'Indiana Jones and the Temple of Doom'." 16 May 1984. Variety. Web. 26 May 2014.

McDonald, Jason. Will the Poltergeist Remake Be a Kids' Movie? 16 January 2015. Web. 28 January 2015.

Medved, Michael. "New Films Show PG-13 is Hollywood's Trojan Horse." 6 July 2001. Jewish World Review. Web. 26 May 2014.

Newman, Kim. Nightmare Movies: A Critical History of the Horror Film, 1968-88. London: Bloomsbury, 1988. Print.

Pirnia, Garin. 1985: The Last Great Year in Film for Kids and Young Adults. 6 March 2015. Web. 15 March 2015.

Prince, Stephen. A New Pot of Gold: Hollywood Under the Electronic Rainbow, 1980-1989. Berkeley: University of California Press, 2002. Print.

Reagan, Ronald. "Acceptance of the Republican Nomination for President." 17 July 1980. PBS.org. Web. 26 May 2014.

-. "Radio Address to the Nation on Domestic Social Issues." 22 January 1983. The American Presidency Project. Web. 26 May 2014.

—. "Reagan's Farewell Speech." 1988. PBS.org. Web. 26 May 2014.

Rich, Joshua. Entertainment Weekly 6 October 2005: 18. 
Siskel, Gene and Roger Ebert. "Gremlins/ Star Trek III/ Streets of Fire (1984)." 1984. Siskel\&Ebert. Web. 26 May 2014.

The Classification and Rating Association. "Do You Know the System?" July 2012. Film Ratings. Web. 26 May 2014.

-. Why: History of Ratings. n.d. Web. 26 May 2014.

This Film Is Not Yet Rated. Dir. Kirby Dick. 2006. DVD.

Thompson, Kimberley M. and Fumie Yokota. "Violence, Sex, and Profanity in Films: Correlation of Movie Ratings With Content." Medscape General Medicine (2004): n. pag. Web.

Variety. "Review: 'Poltergeist'." 31 December 1981. Variety. Web. 26 May 2014.

Vaughn, Stephen. Freedom and Entertainment: Rating the Movies in an Age of New Media. Cambridge: Cambridge University Press, 2006. Print.

Walker, Alexander. Evening Standard 12 July 1984. Print.

Walsh, David A. "A Validity Test of Movie, Television, and Video-Game Ratings." Pediatrics 107.6 (2001): 1302-1308. Web.

White, James. "The Story Behind Gremlins." 15 September 2009. Total Film. Web. 26 May 2014.

Windolf, Jim. "Q\&A: Steven Spielberg." 2 January 2008. Vanity Fair. Web. 26 May 2014.

Wood, Michael. "Little Devils." New Society 13 December 1984: n. pag. Print.

Wood, Robin. Hollywood from Vietnam to Reagan. New York: Columbia University Press, 1986. Print. Zimmerman, Samuel. "POLTERGEIST" remake has a director. 6 March 2013. Web. 14 January 2015.

\footnotetext{
${ }^{1}$ The censorship side of the debate can be illustrated by the work of Jon Lewis and Stephen Vaughn. Authors such as Cantor, Bushman and Cantor, Walsh or Gentile focus on child protection instead.

${ }^{2}$ Examples of these discussions can be seen in Stephen Prince's work or documentaries like This Film Is Not Yet Rated (Kirby Dick, 2006).

${ }^{3}$ The "ratings creep" is most directly addressed in the work of Thompson and Yokota, Leone and Houle, Leone and Barowski, and Leone and Osborn, but also in the work of other authors, such as Bushman et al.
} 